Пророк С. Ю. / Успішне лікування пацієнтки віком 1 місяць із подовженим інтервалом QТ і множинними...

УДК 616.12-008.1

\title{
Успішне лікування пацієнтки віком 1 місяць із подовженим інтервалом QT і множинними епізодами фібриляції шлуночків
}

\author{
Пророк С. Ю. ${ }^{1}$, Пройдак О. С. ${ }^{1}$, Мешкова М. С. ${ }^{1}$, Доронін О. В. ${ }^{2}$, Руденко Н. М. ${ }^{2}$ \\ ${ }^{1}$ ДУ «Науково-практичний медичний центр дитячої кардіології та кардіохірургії МОЗ України» (Київ) \\ ${ }^{2}$ Національна медична академія післядипломної освіти імені П. Л. Шупика (Київ)
}

\begin{abstract}
Синдром подовженого інтервалу QT (LQTS) є рідкісною патологією, асоційованою з раптовою серцевою смертю. Накопичення досвіду успішного ведення хворих до 1 року життя з LQTS є актуальним питанням. Мета роботи - проаналізувати складний випадок лікування пацієнтки з LQTS. Матеріали та методи. Проведено лікування симптоматичного пацієнта віком 1 міс. з LQTS. Результати та обговорення. Нами було успішно застосовано епікардіальну електрокардіостимуляцію у поєднанні з $\beta$-блокаторами. Висновки. У пацієнтів до 1 року життя з LQTS та нестабільною гемодинамікою призначення максимальних доз $\beta$-блокаторів та епікардіальна електрокардіостимуляція $є$ ефективним методом лікування.
\end{abstract}

Ключові слова: синдром подовженого інтервалу QT, електрокардіостимуляція, $\beta$-блокатори.

Синдром подовженого інтервалу QT (LQTS) є рідкісною, клінічно значущою патологією, асоційованою з раптовою серцевою смертю. При дослідженні генетичного матеріалу померлих немовлят із діагнозом «синдром раптової малюкової смерті» маркери LQTS були виявлені у $50 \%$ випадків [1].

Одним із прогностичних критеріїв перебігу хвороби є вік на момент маніфестації клінічних проявів. Наявність епізодів поліморфної тахікардії з синкопальними станами у дітей до 1 року є прогностично несприятливим фактором [2]. Зважаючи на велику небезпеку для життя була виділена окрема нозологія - злоякісний перинатальний синдром подовженого інтервалу QT [3].

Результати лікування даної групи пацієнтів залишаються задовільними, проте оптимальна тактика не визначена [3]. Одним із підходів, описаних у сучасній літературі, $є$ застосування високих доз $\beta$-блокаторів у поєднанні з імплантацією постійного електрокардіостимулятора (EKC) $[4,5]$. Результати такого лікування досить обнадійливі, але такий підхід не описаний як стандартна тактика для дітей віком до 1 року.

3 огляду на рідкість даної патології і важкість перебігу, накопичення досвіду успішного ведення хворих зі злоякісним перинатальним синдромом подовженого інтервалу QT є актуальним питанням.

Мета роботи - представити клінічний випадок успішного лікування пацієнтки 3 перинатальним синдромом подовженого інтервалу QT із застосуванням епікардіальної електрокардіостимуляції та $\beta$-блокаторів.

Матеріали та методи. У дівчинки віком 1 міс. на фоні психоемоційного збудження розвинувся синкопальний стан із подальшим кардіореспіраторним арестом.
Перша медична допомога була надана бригадою карети швидкої медичної допомоги, що після приїзду констатувала клінічну смерть і розпочала серцево-легеневу реанімацію. В подальшому пацієнтка доставлена у ДКЛ № 2 міста Києва, звідки переведена у відділення реанімації ДУ «НПМЦДКК МОЗ України» з діагнозом «шлуночкова тахікардія, стан після серцево-легеневої реанімації».

На момент госпіталізації хвора була у важкому стані, на апараті штучної вентиляції легень. При об'єктивному огляді шкірні покриви сіро-ціанотичні, $\mathrm{SaO} 220 \%$, ЧСС 80 уд./хв. За даними ЕхоКГ, фракція викиду лівого шлуночка становила $10 \%$. На ЕКГ виявлена функціональна блокада атріовентрикулярного (AB) проведення 2:1, 3:1 (рис. 1). При найменших проявах активності відмічалися епізоди поліморфної шлуночкової тахікардії з переходом у фібриляцію шлуночків. Коригований інтервал QТ складав 600 мсек, на підставі чого виставлено діагноз «синдром вродженого подовженого інтервалу QТ» (рис. 2).

3 метою усунення додаткової адренергічної стимуляції серця була поглиблена седація пацієнтки. В якості патогенетичного лікування було призначено метопролол у дозі 2 мг/кг на добу з подальшим поступовим збільшенням дози протягом 16 діб до 8 мг/кг на добу. Доза збільшувалася поступово, із кроком в 2 мг/ кг на добу кожні 4-6 днів залежно від стану дитини. 3 огляду на нестабільну гемодинаміку, схильність до гіпотензії, брадикардію (60-80 уд./хв.), зумовлену функціональною блокадою АВ-проведення, і необхідність призначати максимальні дози $\beta$-блокаторів, на другу добу прийнято рішення нав'язати тимчасову двокамерну епікардіальну ЕКС через серединну стернотомію. 


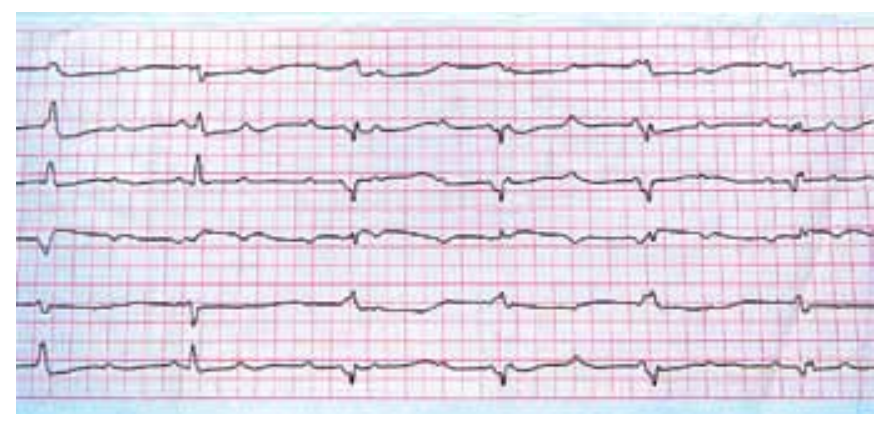

Рис. 1. Функціональна блокада АB-проведення 2:1, 3:1

Застосована лікувальна тактика дозволила стабілізувати стан пацієнтки. Відмічалася значна позитивна динаміка, у зв'язку з чим через 9 діб після застосування тимчасового ЕКС прийнято рішення імплантувати постійний епікардіальний двокамерний ЕКС. Це дозволило поступово збільшити добову дозу метопрололу до 8 мг/кг на добу.

Хвора була виписана зі стаціонару у доброму стані через 31 день після госпіталізації, без ознак неврологічного дефіциту і з повним відновленням скоротливої функції лівого шлуночка.

Наступний контрольний огляд пацієнтки проводився через 1 міс. та через 6 міс. 3 моменту виписки.

Результати та обговорення. Протягом 6 місяців стан дитини залишався стабільним, жодного епізоду шлуночкової тахікардії або синкопе зареєстровано не було. При перевірці роботи ЕКС спостерігався переважно синусовий ритм із короткими періодами стимуляції у режимі DDD. Фізичний і психомоторний розвиток дитини відповідав віковим нормам.

Застосування терапії максимальними дозами $\beta$-блокаторів у поєднанні з епікардіальною двокамерною ЕКС було ключовою терапією, що сприяла успішному лікуванню даної хворої. Незважаючи на те, що метопролол значно поступається в терапевтичній ефективності нодалолу і пропранололу в даній групі пацієнтів [6], вибір препарату був зумовлений коротким часом дії, а отже, більш контрольованим впливом, що вкрай важливо в умовах нестабільної гемодинаміки.

Іншим фактором, що сприяв виживанню пацієнтки, була своєчасно надана перша медична допомога 3 подальшим транспортуванням у спеціалізовану клініку. Тому для покращення виживаності пацієнтів даної групи цілком виправдане скринінгове проведення ЕКГ-дослідження всім новонародженим з метою своєчасного виявлення групи ризику.

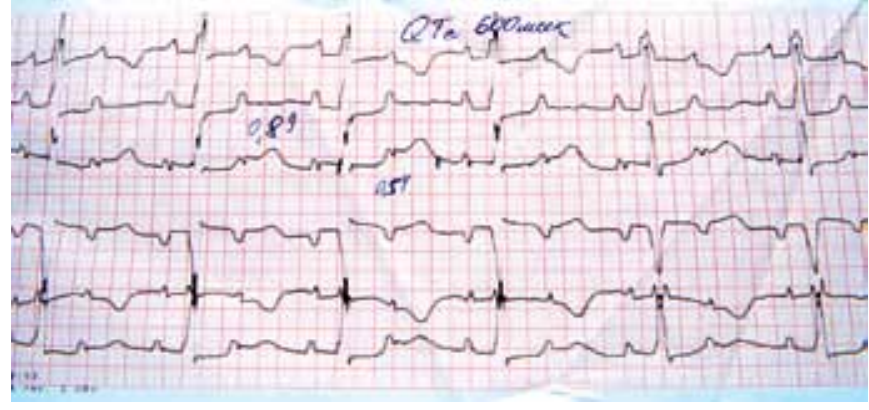

Pис. 2. Синдром вродженого подовженого інтервалу QT

В сім'ях, де було виявлено дітей із безсимптомним подовженням інтервалу QT, доцільно провести навчання батьків і родичів основам серцево-легеневої реанімації у випадку маніфестації хвороби, що могло б збільшити вірогідність своєчасного надання першої медичної допомоги.

Висновки. Епікардіальна ЕКС та призначення високих доз $\beta$-блокаторів $є$ ефективним методом лікування у пацієнтів до року з функціональною блокадою $\mathrm{AB}$-проведення та нестабільною гемодинамікою.

Для підвищення шансів виживаності пацієнтів із вродженим LQTS доцільним є своєчасне виявлення групи ризику. Батькам і родичам дітей із групи ризику слід пройти навчання поводженню в ситуації прояву симптомів хвороби.

\section{Література}

1. Prolongation of the QTinterval and the sudden infant death syndrome / Schwartz P. J., Stramba-Badiale M., Segantini A. et al. // N Engl J Med Overseas Ed. - 1998. Vol. 338. - P. 1709-14.

2. Monteforte N., Napolitano C., Priori S. G. Genetics and arrhythmias: diagnostic and prognostic applications // Rev Esp Cardiol. - 2012. - Vol. 65. - P. 278-86.

3. Douglas P. Zipes. Cardiac Electrophysiology: From Cell to Bedside Sixth Edition, 2013.

4. The Jervell and Lange-Nielsen syndrome; atrial pacing combined with Я-blocker therapy, a favorable approach in young high-risk patients with long QT syndrome? / Frbh A., Siem G., Holmstrцm H. et al. // Heart Rhythm. 2016 Nov. - Vol. 13 (11). - P. 2186-2192. doi: 10.1016/j. hrthm.2016.07.020. Epub 2016 Jul 20.

5. Permanent cardiac pacing in patients with the long QT syndrome / Michael Eldar, Jerry C. Griffin, Joseph A. Abbott et al. // Journal of the American College of Cardiology. -1987 Sep. - Vol. 10, Issue 3. -P. 600-607.

6. Long QT syndrome-associated mutations in intrauterine fetal death / Crotti L., Tester D. J., White W. M. et al. // JAMA. - 2013. - Vol. 309. - P. 1473-1482, 
Пророк С. Ю. / Успішне лікування пацієнтки віком 1 місяць із подовженим інтервалом QT і множинними...

\section{Successful treatment of a patient aged 1 month with long QT syndrome and multiple episodes of ventricular fibrillation}

Prorok S. Yu. ${ }^{1}$, Proidak O. S. ${ }^{1}$, Meshkova M. S. ${ }^{1}$, Doronin O. V. ${ }^{2}$, Rudenko N. M. ${ }^{2}$

${ }^{1}$ State Institution "Scientific and Practical Centre for Pediatric Cardiology and Cardiac Surgery of the MoH of Ukraine" (Kyiv)

${ }^{2}$ P. L. Shupyk National Academy of Postgraduate Education (Kyiv)

Long QT syndrome (LQTS) is a rare condition associated with sudden cardiac death. Accumulation of experience of the successful management of patients under the age of 1 year old with LQTS is a relevant issue. Objective. To analyse the complex case of treatment of a patient with LQTS. Materials and methods. Treatment of a symptomatic patient aged 1 month with LQTS was performed. Results and discussion. We have a successful experience of epicardial pacing in combination with $\beta$-blockers. Conclusion. Prescription of $\beta$-blocker maximal doses and epicardial pacing is the efficient treatment method in patients under 1 year of age with LQTS and unstable hemodynamics.

Key words: long $Q T$ syndrome, pacing, $\beta$-blockers. 